American Journal of Environmental Sciences 7 (6): 505-509, 2011

ISSN 1553-345X

(C) 2011 Science Publications

\title{
Investigation of Deforestation on the Runoff-Peak by KINFIL Model
}

\author{
${ }^{1}$ Alireza Mardookhpour and ${ }^{2}$ Leila Ooshaksaraie \\ ${ }^{1}$ Department of Civil and Water Engineering, \\ ${ }^{2}$ Department of Environmental Engineering, \\ Islamic Azad University, Lahijan Branch, PO Box, 1616, Iran
}

\begin{abstract}
Problem statement: In present study the KINFIL model was used for the catchment management, including the investigation of deforestation on predict flood runoff assessment with a significant precision. Approach: The KINFIL rainfall-runoff model has been used for the reconstruction of the rainfall runoff events in agricultural land use. The implementation of the KINFIL model supported by GIS proved to be a proper method for the flood runoff assessment on Sepidroud catchments (north of Iran), during which different scenarios of the rainfall events. Results: The results show when the observed discharge peak was $2.25 \mathrm{~m}^{3} \mathrm{sec}^{-1}$, the computed discharge by the KINFIL model predicted $2.4 \mathrm{~m}^{3} \mathrm{sec}^{-1}$ (about 7\% errors) and when the observed discharge peak was $1.9 \mathrm{~m}^{3}$ $\mathrm{sec}^{-1}$, the computed discharge by the KINFIL model predicted $1.8 \mathrm{~m}^{3} \mathrm{sec}^{-1}$ (about 5\% errors). Also, the results showed when deforestation reaches $10 \%$ of total primitive areas in Sepidroud basin; the runoffpeak may increase more than 14.5 times. Conclusion/Recommendations: It can be stated that utilizing KINFIL model for determining the peak of discharge in agricultural land use, is a hydrological model, which has the good convergence with observed data.
\end{abstract}

Key words: KINFIL, design discharge peak, runoff, GIS, deforestation

\section{INTRODUCTION}

Recent development in hydrological modeling provides modern methods of runoff forecasting and techniques for the prediction of design discharges impacted by human activities (Kovar et al., 2002). These $\mathrm{N}$-year design discharges caused by the design rainfalls play a significant role in the new investments (Beven, 2004). The catchment management, including the land use, plays an important role in the rainfallrunoff relationships. The implementation of hydrological models allows a better analysis of the flood situations in agricultural lands. The reliability of these data varies and one possible way to improve it is the use of hydrological models. One of these models, simulating the direct runoff from ungauged catchments is the KINFIL model (Kaldec and Lovar, 2009). The direct runoff simulation has been computed using the kinematics wave sub-model (i.e., KINFIL model) respecting the catchment topography. Topographical characteristics of the Sepidroud catchment were processed by the ARC/INFO system. The reliability of these modern methods of hydrological modeling and their GIS interface is relevant for an adequate mathematical description of the rainfall-runoff process.

\section{MATERIALS AND METHODS}

The KINFIL model uses the Curve Number method (Cronshey, 1986) but suppresses its weak theoretical background by substituting the physicallybased infiltration theory for a common empirical $\mathrm{CN}$ approach. The correspondence between $\mathrm{CN}$ values and soil parameters, such as the saturated hydraulic conductivity (KS) and sorptivity (Sf), was derived through a correlation technique of these parameters with the design rainfalls. The infiltration part of the model is based on the Morel-Seytoux equations (McCulloch and Robinson, 1993), based on the GreenAmpt concept, distinguishing the pre- and post-ponding infiltrations from the constant or variable rainfalls. It is always disputable if the Green-Ampt approximation is adequate to simulate the infiltration process on forested mountainous catchments. The KINFIL model uses this approximation in combination with the SCS Curve Number method based on the Morel-Seytoux (1982) approach. The second basic component of the KINFIL model is the simulation of the runoff.

Corresponding Author: Alireza Mardookhpour, Department of Civil and Water Engineering, Islamic Azad University, Lahijan Branch, PO Box, 1616, Iran Tel: 0098211992399 
Am. J. Environ. Sci., 7 (6): 505-509, 2011

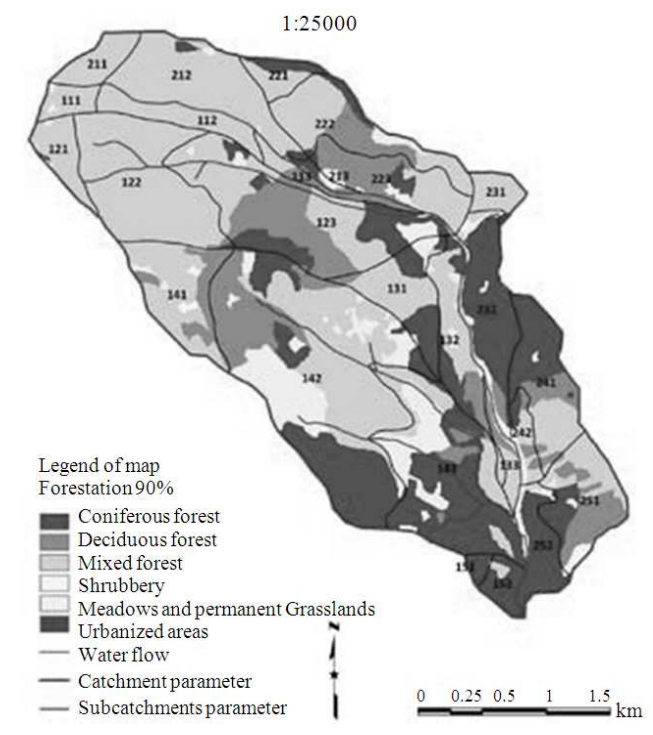

Fig. 1: Land use in the sepidroud catchment

This process is based on a kinematics wave approximation of the model (Brakensiek and Rawls, 1982). In the cases of high rainfall intensities as it is always in the design floods when those are often higher that $2 \mathrm{~mm} \mathrm{~min}^{-1}$ and their depth is over $50 \mathrm{~mm}$, the conditions for using a kinematics wave are mostly feasible. For the numerical solution, the explicit LaxWendroff finite difference scheme was implemented. It should also be stated that the infiltration part of the KINFIL model has two parameters, KS and Sf, strictly dependent on the $\mathrm{CN}$ values which are not subjected to a change through calibration. However, each of these partial areas has its own $\mathrm{CN}$-value characterizing the rainfall excess conditions (Kaldec and Lovar, 2009). The routing part of the model has two groups of parameters-geometrical parameters of partial subcatchments (at least the width and length of rectangles, or segment parameters) that have to be used and the Manning roughness (Overton and Meadows, 1976; Wannawong et al., 2010). This model was used for the Sepidroud catchment data. Table 1 shows the land use in this catchment. The spatial properties of the Sepidroud catchment are characterized in the raster maps based on the topographical maps 1:25 000 (Fig. 1). Graphical inputs/ outputs were made in GIS ArcView and ArcGIS (version 9.0). GIS tools for catchment identification in the form of DTM including the topographical characteristics, soil groups, land use and water drainage pattern in this study, were used. All these characteristics are given in Table 2 (Swank and Crossley, 1988).

Average yearly temperatures vary between 6 degrees(c) and 33 degrees(c). Average yearly precipitations amount to 857 and $1320 \mathrm{~mm}$.
Table 1: Land use in the Sepidrod catchment

\begin{tabular}{lcr}
\hline Land use & Area $\left(\mathrm{km}^{2}\right)$ & Percentage \\
\hline Coniferous forest & 2.81 & 26.06 \\
Deciduous forest & 15.18 & 1.64 \\
Mixed forest & 5.24 & 48.56 \\
Shrubbery & 0.06 & 0.50 \\
Meadows and permanent & & \\
Grasslands & 0.91 & 8.47 \\
Urbanized areas & 0.01 & 0.03 \\
Road network & 0.13 & 1.20 \\
\hline
\end{tabular}

Table 2: Basic characteristics of experimental Sepidroud catchment

\begin{tabular}{llr}
\hline Catchm catchment area $\left(\mathrm{km}^{2}\right)$ & $\mathrm{Sp}$ & 10.8 \\
\hline Forested catchment area $(\mathrm{km} 2)$ & $\mathrm{SL}$ & 9.840 \\
Forestation $(\%)$ & 1 & 90.140 \\
Length of river $(\mathrm{km})$ & $\mathrm{L}$ & 6.438 \\
Length of inflows $(\mathrm{km})$ & L $)$ & 9.263 \\
Catchment perimeter $(\mathrm{km})$ & $\mathrm{O}$ & 14.905 \\
Length of talweg $(\mathrm{km})$ & $\mathrm{Lu}$ & 6.834 \\
Max. Catchment altitude (a.s.l.) & $\mathrm{H}$ max & 1158.000 \\
Min. catchment altitude (a.s.l.) & $\mathrm{H}$ min & 569.000 \\
Average catchment altitude (a.s.l.) & $\mathrm{H}$ ave & 909.860 \\
Average width catchment (km) & Bp & 1.580 \\
Average river slope $(\%)$ & $\mathrm{It}$ & 15.750 \\
Average talweg slope $(\%)$ & $\mathrm{Iú}$ & 12.340 \\
Average catchment slope $(\%)$ & $\mathrm{Is}$ & 31.150 \\
\hline
\end{tabular}

\section{RESULTS}

When the first flood (Wave 1) came, the catchment had been moderately saturated with the previous precipitations to the level of antecedent moisture conditions AMC II (Tani and Abe, 1987), during the second wave (Wave 2) the catchment was extremely saturated (level AMC III), as a consequence of which the culmination inflow was higher, even though the precipitation was much lower in this case (Table 3 ).

The AMC I to III are classified according to the U.S. Soil Conservation Service Method to distinguish between the levels of saturation with precipitation depths during five previous days (AI to $36 \mathrm{~mm}$, AII from $36-53 \mathrm{~mm}$ and AIII more than $53 \mathrm{~mm}$ ) (Kaldec and Lovar, 2009; Cronshey, 1986). These sudden intensive rainfalls caused floods which, with their peaks of 2.25 and $1.8 \mathrm{~m}^{3} \mathrm{sec}^{-1}$, may be classified in the category of the recurrence time $\mathrm{N}=2$ years. Each subcatchment was differentiated mainly according to the parameters of the slope inclination and the soil and land use. The cascades were determined with 2-3 elements with the help of GIS. In total, 10 basic sub-catchments were identified in the runoff processes. All subcatchments were reoriented towards rectangular elements of the cascade in the same area. This procedure is schematically represented in and Table 4. The simulation was undertaken of the scenarios of the flood runoff from $\mathrm{N}$-year design rainfall exceedence probability and return period $\mathrm{p}=0.01(\mathrm{~N}=100$ years $)$. 
Am. J. Environ. Sci., 7 (6): 505-509, 2011

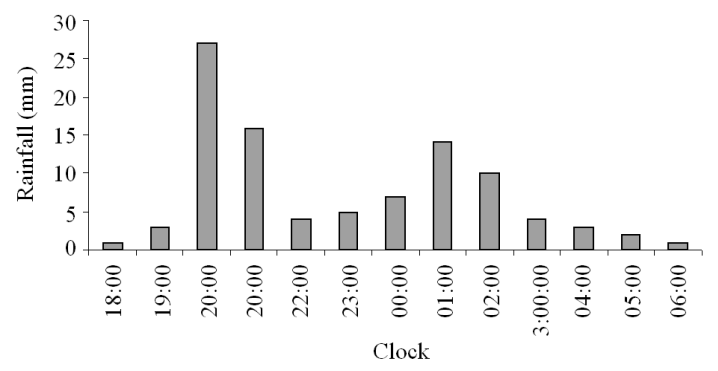

Fig. 2: Total rainfall (16. 09. 2005)

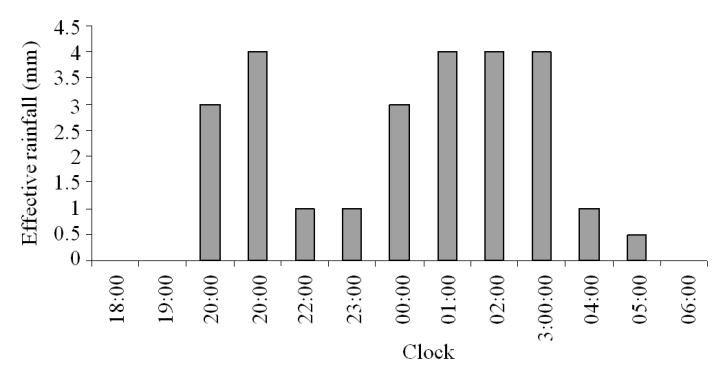

Fig. 3: Effective rainfall (16. 09. 2005)

Table 3: Basic information on rainfall-runoff events in the Sepidroud catchment

\begin{tabular}{lcc}
\hline Sepidroud Catchment & Wave1 & Wave2 \\
\hline $\begin{array}{l}\text { Beginning of } \\
\text { causal Rainfall }\end{array}$ & 16.09 .2005 & 11.10 .2006 \\
& $18: 00$ & $15: 00$ \\
End of causal rainfall & 17.09 .2005 & 12.10 .2006 \\
& $06: 00$ & $01: 00$ \\
Peak flow $\left(\mathrm{m}^{3} \mathrm{sec}^{-1}\right)$ & 2.25 & 1.8 \\
Total depth of & 81.10 & 18.60 \\
causal rainfall $(\mathrm{mm})$ & & \\
$\begin{array}{l}\text { Total depth of } \\
\text { effective rainfall }(\mathrm{mm})\end{array}$ & 8.13 & 9.05 \\
\hline
\end{tabular}

The total rainfall and effective rainfall of the recorded gauge have been submitted in Fig. 2 and 3 for the precipitation of (16. 09. 2005 18:00 ----17. 09. 2005 06:00).

\section{DISCUSSION}

The computed discharge by KINFIL model and observed discharge are compared in Fig. 4.

According to Fig. 4, the computed peak of discharge by KINFIL model reached to $2.4 \mathrm{~m}^{3} \mathrm{sec}^{-1}$ and the observed peak of discharge reached to $2.25 \mathrm{~m}^{3} \mathrm{sec}^{-1}$. So, the precision of the computed discharge by KINFIL model is $7 \%$ approximately. Also the total rainfall and effective rainfall of the recorded gauge have been submitted in Fig. 5 and 6 for the precipitation of (11. 10. 2006 15:00 ----12. 10. 2006 03:00).

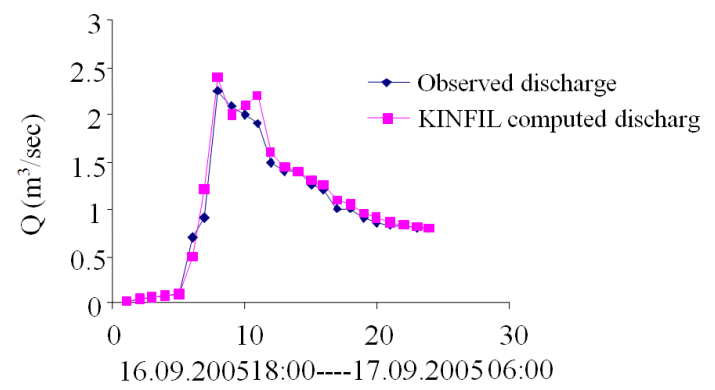

Fig. 4: Measured and computed discharges of the KINFIL model (16. 09. 2005 18:00 ------17. 09. 200 06:00)

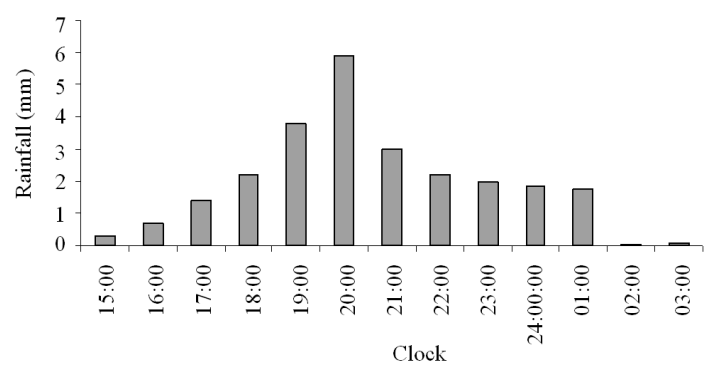

Fig. 5: Total rainfall (11. 10. 2006)

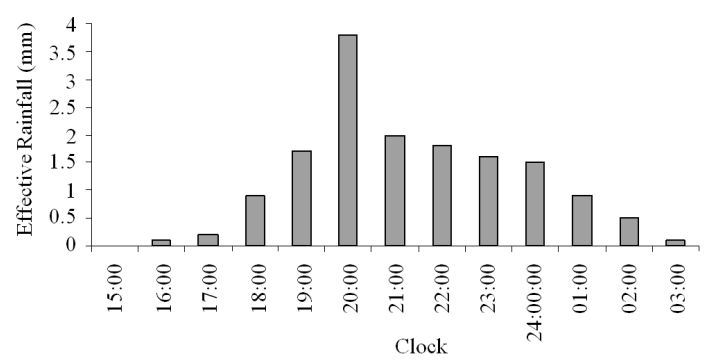

Fig. 6: Effective rainfall (11. 10. 2006)

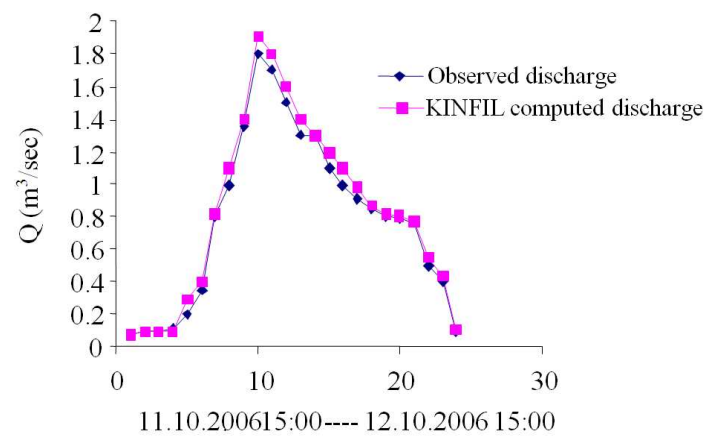

Fig. 7: Measured and computed discharges of the KINFIL model (11. 10. 2006 15:00------11. 10. 2006 15:00) 
Am. J. Environ. Sci., 7 (6): 505-509, 2011

Table 4: Scheme of the Sepidroud catchment (According to Fig. 1)

\begin{tabular}{|c|c|c|c|c|c|c|}
\hline Cascade & Area $\left(\mathrm{km}^{2}\right)$ & Plane No. & Area v & Average width $(\mathrm{Km})$ & Length $(\mathrm{Km})$ & slope (-) \% \\
\hline \multirow[t]{3}{*}{$\overline{\mathrm{DP} 1}$} & 0.418 & 111 & 0.102 & 3.248 & 0.031 & 0.320 \\
\hline & & 112 & 0.216 & & 0.067 & 0.360 \\
\hline & & 113 & 0.100 & & 0.031 & 0.195 \\
\hline \multirow[t]{3}{*}{ DP2 } & 2.148 & 121 & 0.170 & 2.961 & 0.057 & 0.304 \\
\hline & & 122 & 0.863 & & 0.291 & 0.434 \\
\hline & & 123 & 1.115 & & 0.376 & 0.316 \\
\hline \multirow[t]{3}{*}{ DP3 } & 0.831 & 131 & 0.377 & 2.426 & 0.155 & 0.286 \\
\hline & & 132 & 0.362 & & 0.149 & 0.254 \\
\hline & & 133 & 0.092 & & 0.038 & 0.377 \\
\hline \multirow[t]{3}{*}{ DP4 } & 3.600 & 141 & 0.474 & 3.938 & 0.120 & 0.348 \\
\hline & & 142 & 2.081 & & 0.538 & 0.317 \\
\hline & & 143 & 1.045 & & 0.265 & 0.278 \\
\hline \multirow[t]{2}{*}{ DP5 } & 0.146 & 151 & 0.036 & 0.418 & 0.086 & 0.266 \\
\hline & & 152 & 0.110 & & 0.263 & 0.363 \\
\hline \multirow[t]{3}{*}{ DP6 } & 0.811 & 211 & 0.153 & 2.733 & 0.056 & 0.380 \\
\hline & & 212 & 0.618 & & 0.226 & 0.377 \\
\hline & & 213 & 0.040 & & 0.015 & 0.172 \\
\hline \multirow[t]{3}{*}{ DP7 } & 0.994 & 221 & 0.126 & 0.821 & 0.153 & 0.218 \\
\hline & & 222 & 0.479 & & 0.583 & 0.350 \\
\hline & & 223 & 0.389 & & 0.474 & 0.329 \\
\hline \multirow[t]{2}{*}{ DP8 } & 0.689 & 231 & 0.115 & 1.794 & 0.064 & 0.344 \\
\hline & & 232 & 0.483 & & 0.269 & 0.310 \\
\hline \multirow[t]{2}{*}{ DP9 } & 0.569 & 241 & 0.455 & 0.379 & 1.200 & 1.610 \\
\hline & & 242 & 0.114 & & 0.301 & 0.363 \\
\hline \multirow[t]{2}{*}{ DP10 } & 0.680 & 251 & 0.438 & 1.127 & 0.389 & 0.178 \\
\hline & & 252 & 0.242 & & 0.215 & 0.320 \\
\hline
\end{tabular}

Table 5:Design discharges $\left(\mathrm{m}^{3} \mathrm{sec}^{-1}\right)$ in the Sepidroud catchment, return period of 100 years

\begin{tabular}{lllr}
\hline & & $\mathrm{Td}=60(\mathrm{~min})$ & \\
& $\mathrm{Td}=30(\mathrm{~min})$ & Runoff $\left(\mathrm{m}^{3} / \mathrm{sec}\right)$ & $\mathrm{Td}=300(\mathrm{~min})$ \\
\hline Forestation $(10 \%)$ & 27.5 & 37.8 & 11.65 \\
Forestation $(50 \%)$ & 22.1 & 31.5 & 8.30 \\
Forestation (90\%) & 18.5 & 20.5 & 6.40 \\
\hline
\end{tabular}

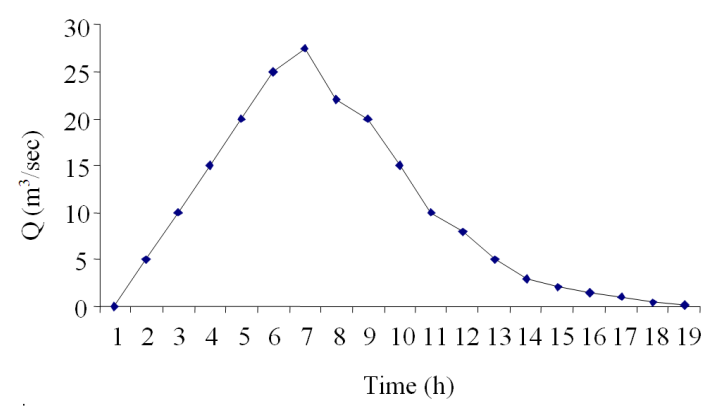

Fig. 8: Computed discharges of the KINFIL model for deforestation $10 \%$ and $t d=30 \mathrm{~min}$

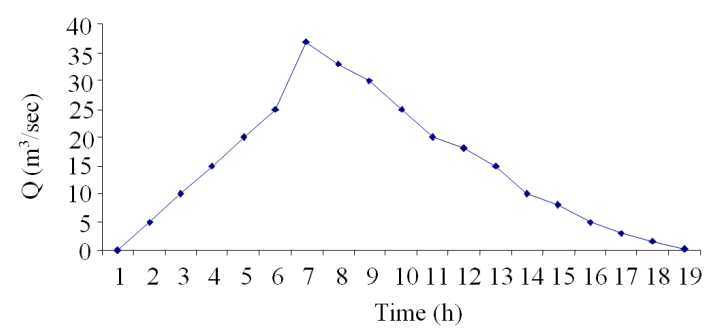

Fig. 9: Computed discharges of the KINFIL model for deforestation $10 \%$ and $\mathrm{td}=60 \mathrm{~min}$

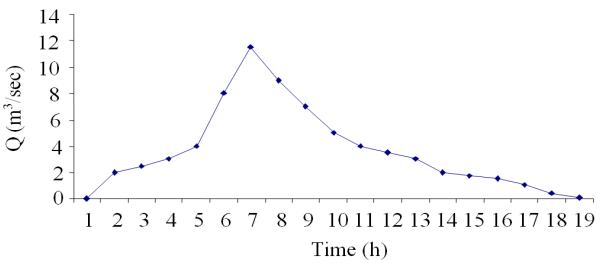

Fig. 10: Computed discharges of the KINFIL model for deforestation $10 \%$ and $\mathrm{td}=300 \mathrm{~min}$

Also, the computed discharge by KINFIL model and observed discharge are compared in Fig. 7. According to Fig. 7, the computed peak of discharge by KINFIL model reached to $1.9 \mathrm{~m}^{3} \mathrm{sec}^{-1}$ and the observed peak of discharge reached to $1.8 \mathrm{~m}^{3} \mathrm{sec}^{-1}$. So, the precision of the computed discharge by KINFIL model is 5\% approximately. Also deforestation Scenario simulations in Sepidroud basin area when the forested areas, which cover almost $90 \%$ of the catchment area, were replaced with permanent grass, which means the reduction of the forested area to 90,50 and $10 \%$, respectively.

The KINFIL computation results, showed, the increase in design discharges $\left(\mathrm{m}^{3} \mathrm{sec}^{-1}\right)$ more than 14.5 times with an event duration of $\mathrm{td}=30,60,300 \mathrm{~min}$, return period of 100 years and scenario changes of forestation (Fig. 8-10 and Table 5).

\section{CONCLUSION}

It can be stated that utilizing KINFIL model for determining the peak of discharge in agricultural land 
use, is a hydrological model, which has the good convergence with observed data. According to the obtained results, when the precipitation had high intensity (more than $25 \mathrm{~mm} \mathrm{~h}^{-1}$ ), the computed peak of discharge by KINFIL model reached to $2.4 \mathrm{~m}^{3} \mathrm{sec}^{-1}$ and the observed peak of discharge reached to $2.25 \mathrm{~m}^{3}$ $\mathrm{sec}^{-1}$. So, the precision of the computed discharge by KINFIL model is 7\% approximately. Also, when the precipitation had low intensity (less than $6 \mathrm{~mm} \mathrm{~h}^{-1}$ ), the computed peak of discharge by KINFIL model reached to $1.9 \mathrm{~m}^{3} \mathrm{sec}^{-1}$ and the observed peak of discharge reached to $1.8 \mathrm{~m}^{3} \mathrm{sec}^{-1}$. So, the precision of the computed discharge by KINFIL model is $5 \%$ approximately. Also The KINFIL computation results, showed, the increase in design discharges37.8-2.4 $\mathrm{m}^{3}$ $\mathrm{sec}^{-1}$ (more than 14.5 times) with an event duration of $\mathrm{td}=60 \mathrm{~min}$, return period of 100 years.

\section{ACKNOWLEDGMENT}

This project was financially supported by Islamic Azad University of Lahijan-Iran.

The writers whish to thank for equipments and software supported by Islamic Azad University of Lahijan-Iran.

\section{REFERENCES}

Beven, K.J., 2004. Rainfall-Runoff Modeling: The Primer. 1st Edn., John Wiley and Sons, Chichester, ISBN-10: 0470866713, pp: 372.

Brakensiek, D.L. and W.J. Rawls, 1982. An infiltration based runoff model for a standardized $24 \mathrm{~h}$ rainfall. Trans. ASABE, 25: 1607-1611.

Kaldec, V. and P. Lovar, 2009. Use of the KINFIL rainfall-runoff model on the hukava catchment. J. Soil Water Res.
Kovar, P., P. Cudlin, M. Herman, F. Zemek and M. Korytar, 2002. Analysis of flood events on small river catchments using the KINFIL model. J. Hydrol. Hydromech., 50: 158-171.

McCulloch, J.S.G. and M. Robinson, 1993. History of forest hydrology. J. Hydrol., 150: 189-216. DOI: 10.1016/0022-1694(93)90111-L

Morel-Seytoux, H.J, 1982. Analytical results for prediction of variable rainfall infiltration. $\mathrm{J}$. Hydrol., 59: 209-230. DOI: 10.1016/00221694(82)90088-9

Overton, D.E. and M.E. Meadows, 1976. Stormwater Modeling. 1st Edn., Academic Press, London, ISBN-10: 0125315503, pp: 358.

Swank, W.T. and D.A. Crossley, 1988. Forest Hydrology and Ecology at Coweeta. 1st Edn., Springer-Verlag, New York, ISBN: 0387965475, pp: 469.

Tani, M. and T. Abe, 1987. Analysis of stormflow and its source area expansion through a simple kinematic wave equation. Proceedings of the Vancouver Symposium Forest Hydrology and Watershed Management (FHWM' 87), Japan, pp: 609-615.

Cronshey, R., 1986. Urban Hydrology for Small Watersheds. 2nd Edn., U.S. Department of Agriculture, Soil Conservation Service, Engineering Division, Washington DC., pp: 162.

Wannawong, W., U.W. Humphries, P. Wongwises, S. Vongvisessomjai and W. Lueangaram, 2010. A two-dimensional wave prediction model along the best track of typhoon Linda 1997. Am. J. Environ. Sci., 6: 280-285. DOI: 10.3844/ajessp.2010.280.285 